\title{
SHIELDING THE PRESUMPTION OF INNOCENCE FROM PRETRIAL MEDIA COVERAGE
}

\author{
ARIANA TANOOS*
}

\section{INTRODUCTION}

William Blackstone coined the famous phrase now referred to as the Blackstone Formulation: "[B]etter that ten guilty persons escape than that one innocent suffer." American criminal law is founded on the concept that a defendant is innocent until proven guilty. ${ }^{2}$ This presumption of innocence was regarded by ancient cultures with the utmost importance; even centuries ago, as early as 1792 B.C., it was recognized that punishing an innocent person was far worse than allowing a criminal to go free. ${ }^{3}$ But thousands of years later, pretrial publicity of criminal cases is eroding the presumption through inconsistent Supreme Court jurisprudence. ${ }^{4}$ This has caused a deterioration of the presumption's strength, leading to public attitudes that resemble more closely a presumption of guilt. ${ }^{5}$ Each day, countless reports of local, regional, and national crime stories dominate news programs, broadcasting mug shots and perp walks while reporting details about the defendant, the defendant's criminal history, and details of the offense. ${ }^{6}$ Public suspicion and pretrial deliberation about a defendant's guilt have become commonplace, contaminating jury pools to a greater extent than ever before and jeopardizing defendants' Fourteenth Amendment right to a fair trial. ${ }^{7}$

The weakening of the presumption of innocence has allowed the press to take greater liberty in reporting on crime, reporting inaccuracies that the public accepts

* J.D. Candidate, 2017, Indiana University Robert H. McKinney School of Law; B.S., 2014, University of Evansville. I would like to thank Dr. Deborah Howard for sparking my interest in legal studies, Dr. Kevin Gray for first allowing me to explore this subject in the context of criminal justice, and Professor Lahny Silva for her constant guidance in developing a note of publishable quality from what would have otherwise been a preempted topic. I would also like to thank my family and my fiancé, John Goth, for their encouragement and support during my law school endeavors.

1. Coffin v. United States, 156 U.S. 432, 456 (1895).

2. Shima Baradaran, Restoring the Presumption of Innocence, 72 OнIо ST. L.J. 723, 728 (2011).

3. Francois Quintard-Morenas, The Presumption of Innocence in the French and AngloAmerican Legal Traditions, 58 AM. J. Comp. L. 107, 110-14 (2010).

4. In re Winship, 397 U.S. 358, 363 (1970); Coffin, 156 U.S. at 460.

5. Baradaran, supra note 2, at 726-27.

6. See generally Franklin D. Gillian, Jr. \& Shanto Iyengar, Prime Suspects: The Influence of Local Television News on the Viewing Public, 44 AM. J. Pol. SCI. 560, 561-62 (2000); DANILO Yanich, Ctr. For Cmty. Dev. \& Family Policy \& Graduate Sch. of Urban AfFairs \& Pub. Policy, Univ. of Del., Crime, Community \& local tV News: Covering Crime in Philadelphia AND Baltimore 33-34 (1998).

7. Edmond Constantini \& Joel King, The Partial Juror: Correlates and Causes of Prejudgment, 15 LAw \& Soc. Rev. 9, 36-38 (1981). 
as confirmed facts. ${ }^{8}$ Freedom of the press is continuously promoted and preserved at the expense of the presumption of innocence. ${ }^{9}$ To keep pretrial media coverage from infringing on a criminal defendant's Fifth, Sixth, and Fourteenth Amendment rights, the presumption of innocence must be shielded from pretrial media. $^{10}$

The purpose of this Note is to advocate for courts and lawmakers to adopt methods to shield the presumption of innocence from the damaging effects of pretrial media coverage to balance the press's First Amendment freedoms with the constitutional rights afforded criminal defendants by the Fifth, Sixth, and Fourteenth Amendments. This Note recommends that the U.S. criminal justice system (1) reinstate the Supreme Court's holding in Coffin v. U.S. that the presumption of innocence is distinct and separate from the burden of proof, ${ }^{11}(2)$ adopt legislation limiting freedom of the press in criminal matters to provide judges with tools to control pretrial publicity, and (3) make the presumption of innocence an explicit, codified right to emphasize its importance. These measures will strengthen the presumption of innocence-as a separate and individual right - and shield it from further abuse by the press.

Part I of this Note discusses the historical origins of the presumption of innocence from ancient civilizations until the colonization of America. Part II provides an overview of Supreme Court jurisprudence on the presumption of innocence and how combining the principle with the burden of proof in criminal cases has weakened the presumption. Part III addresses how changes in the criminal justice system's bail determinations have further eroded the presumption. Part IV explores the impact pretrial media has on the presumption of innocence, highlighting how technological advances have caused greater need for strengthening the presumption. Part $\mathrm{V}$ analyzes currently available but inadequate methods that courts can employ to limit pretrial media, such as gag orders, changes of venue, and sealing court. Finally, Part VI proposes two new methods to strengthen the presumption that will limit the unrestricted ability of the media to cast suspicion and publicize criminal matters through pretrial media. The goal of these proposals is to preserve the freedom of the press while strengthening the presumption of innocence so that the two may be rebalanced to promote democracy rather than exploiting one for the benefit of the other.

\section{ORIGINS OF THE PRESUMPTION OF INNOCENCE}

The presumption of innocence has been valued as a foundation of criminal

8. Philip L. Judy, The First Amendment Watchdog Has a Flea Problem, 26 CAP. U. L. REV. 541, 547-49, 581-82 (1997).

9. Id. at 541 .

10. Estelle v. Williams, 425 U.S. 501, 503 (1976) ("The right to a fair trial is a fundamental liberty secured by the Fourteenth Amendment. . . The presumption of innocence, although not articulated in the Constitution, is a basic component of a fair trial under our system of criminal justice.”); Duncan v. Louisiana, 391 U.S. 145, 148 (1968).

11. See infra Part II.A. 
law and justice since ancient times. ${ }^{12}$ The presumption of innocence is derived from the ancient maxim that the accuser must prove the guilt of the accused before the accused can be punished. ${ }^{13}$ The Code of Hammurabi, one of the oldest collections of criminal laws, required the accuser to bear the burden of proof to the extent that if the accuser failed to establish the accused's guilt, then the accuser would be punished or even killed. ${ }^{14}$ Though this measure may seem drastic, it emphasized a presumption that a person accused of crime was not considered guilty until proven so; this placed an equal burden on the accuser to ensure that false criminal charges were not made. ${ }^{15}$

Ancient Greece also recognized an accused's right to innocence until conclusive proof of his guilt was established; society had no right to treat the accused as a criminal without it. ${ }^{16}$ In 352 B.C., Greek orator Demosthenes argued that punishment could only be inflicted after trial and conviction because "conscience permits us to inflict punishment according to knowledge, but not before." ${ }^{17}$ Roman law similarly placed the burden of proof on accusers and recognized that it was better to allow a guilty person to go free than to sentence an innocent person to death. ${ }^{18}$ The Constitution of Emperor Antonin of Rome dated 212 A.D. stated, "He who wishes to bring an accusation must have the evidence." 19 Further, an appeal preserved the accused's innocence, despite a guilty conviction, until final judgment. ${ }^{20}$ If an accused person died before conviction, seizure of his property was illegal and his heirs could inherit as if no accusation had been made. ${ }^{21}$

These ancient practices influenced centuries of law. ${ }^{22}$ At the end of the eighth century, King of the Franks and future Holy Roman Emperor Charlemagne adopted a maxim that was used throughout the Middle Ages to emphasize that a defendant should not be presumed guilty prior to conviction: "[I]t is not the accusation, but the conviction that makes the criminal." ${ }^{23}$ Magna Carta implied a presumption of innocence by preventing the king's subjects from imprisonment or punishment except through due process of the law. ${ }^{24}$ In the centuries that followed, the presumption of innocence was promoted through common law principles that the English colonists took with them to America. ${ }^{25}$

12. Quintard-Morenas, supra note 3.

13. Id. at 110 .

14. Id. at 110-11.

15. Id.; Allen H. Godbey, The Place of the Code of Hammurabi, 15 Monist 199, 210 (1905).

16. Quintard-Morenas, supra note 3, at 112.

17. Id.

18. Id. at 111 .

19. Id. (internal quotations omitted) (quoting CODE JUST. 2.1.4 (Antonin 212))

20. Id. at 113 .

21. Id.

22. $I d$.

23. Id.

24. Baradaran, supra note 2, at 727.

25. Id. 
The American colonies were established under the laws of England, and the presumption of innocence thus made its emergence in the New World through the English common law. ${ }^{26}$ The earliest record of the presumption in the colonies comes from the General Court of the Massachusetts Bay Colony in 1657 and states that "in the eye of the law every man is honest and innocent, unless it be proved legally to the contrary." ${ }^{27}$ Following the American Revolution, the colonies continued to uphold the presumption, as can be seen from the writings of Lord Gillies in McKinley's Case in $1817 .{ }^{28}$ "I conceive that this presumption [of innocence] is to be found in every code of law which has reason and religion and humanity for a foundation. It is a maxim which ought to be inscribed in indelible characters in the heart of every judge and juryman . . .."29 The presumption of innocence later became a foundation of American criminal law enshrined in the U.S. constitutional amendments. ${ }^{30}$

\section{U.S. SuPREME COURT JURISPRUdENCE ON THE PRESUMPTION OF INNOCENCE}

The presumption of innocence is not explicitly stated in the U.S. Constitution. ${ }^{31}$ However, it is implied through the due process clauses of the Fifth and Fourteenth Amendments and the Sixth Amendment's right to a fair trial. ${ }^{32}$ After the Constitution was ratified, more than 100 years passed before the Supreme Court first determined whether a presumption of innocence exists in criminal cases. ${ }^{33}$ Since then, the Court's jurisprudence has blurred the line between the presumption of innocence and the evidentiary standard of "beyond a reasonable doubt," causing the presumption to be treated more as a rule of procedure than a substantive right of defendants. ${ }^{34}$ This precedent has led to a weakening of the principle, which will likely go uncorrected without action by the judiciary or the legislature. ${ }^{35}$

\section{A. A Separate, Substantive Right}

In Coffin v. United States, the Court held a presumption of innocence in favor of the accused exists. ${ }^{36}$ Defendants were charged with aiding and abetting the

\section{Id.}

27. Quintard-Morenas, supra note 3, at 130-31.

28. Coffin v. United States, 156 U.S. 432, 456 (1895).

29. Id. (internal quotations omitted) (quoting McKinley's Case, 33 State Tr. 275, 506 (1817)).

30. Id. at 453; Baradaran, supra note 2.

31. Estelle v. Williams, 425 U.S. 501, 503 (1976) ("The presumption of innocence, although not articulated in the Constitution, is a basic component of a fair trial under our system of criminal justice.”).

32. Id:; Brian V. Breheny \& Elizabeth M. Kelly, Maintaining Impartiality: Does Media Coverage of Trials Need to be Curtailed?, 10 J. C.R. \& ECON. DEv. 371, 372-73 (1995).

33. See Coffin, 156 U.S. at 432.

34. Baradaran, supra note 2, at 737-38; see Quintard-Morenas, supra note 3, at 141-49.

35. Id.

36. See Coffin, 156 U.S. at 432. 
former president of the Indianapolis National Bank in bank fraud. ${ }^{37}$ The defendants' requested instruction on the presumption of innocence was denied by the trial court. ${ }^{38}$ The trial court denied the instruction because it found the presumption was encompassed in the given instruction on reasonable doubt. ${ }^{39} \mathrm{To}$ determine whether the defendants were entitled to an instruction on the presumption of innocence in addition to an instruction on reasonable doubt, the Court had to address whether the two principles of law were legally equivalent. ${ }^{40}$ The Supreme Court held the trial court in error and distinguished reasonable doubt from the presumption of innocence. ${ }^{41}$

[Reasonable doubt] is of necessity the condition of mind produced by the proof resulting from the evidence in the cause. It is the result of the proof, not the proof itself; whereas the presumption of innocence is one of the instruments of proof ... from which reasonable doubt arises; thus one is a cause, the other an effect. ${ }^{42}$

The Court further stated, "The principle that there is a presumption of innocence in favor of the accused is the undoubted law, axiomatic and elementary, and its enforcement lies at the foundation of the administration of our criminal law." The Court explicitly recognized that the doctrine of reasonable doubt originates from the presumption of innocence- the two principles, though separate and distinct, are inherently connected. ${ }^{44}$ "The evolution of the principle of the presumption of innocence and its resultant, the doctrine of reasonable doubt, makes more apparent the correctness of these views, and indicates the necessity of enforcing the one, in order that the other may continue to exist." ${ }^{35}$ This was the Court's view of the presumption of innocence for more than half a century, until inconsistent opinion writing created the beginning of the presumption's diminishment. ${ }^{46}$

\section{B. Blurring the Line-Combining the Presumption with the Burden of Proof}

The Court later changed its view that the presumption of innocence and burden of proof were "distinct and separate" principles in In re Winship. ${ }^{47}$ A twelve-year-old juvenile was determined delinquent at an adjudicatory hearing,

\section{Id.}

38. Id. at 452-53.

39. Id. at 456-57.

40. Id. at 458 .

41. Id. at 460-61.

42. Id. at 460 .

43. Id. at 453 .

44. Id. at 460 .

45. Id.

46. See generally In re Winship, 397 U.S. 358 (1970); Casey v. United States, 276 U.S. 413, 428 (1928); Kirby v. United States, 174 U.S. 47, 55-56 (1899); Allen v. United States, 164 U.S. 492, 500 (1896).

47. 397 U.S. at 363; Baradaran, supra note 2, at 737. 
but only by a preponderance of the evidence. ${ }^{48} \mathrm{He}$ appealed, arguing that the Due Process Clause required this determination to be made beyond a reasonable doubt - the same burden of proof that he would have been afforded as an adult. ${ }^{49}$ The Court determined that "due process and fair treatment" of the Fourteenth Amendment required a burden of proof beyond a reasonable doubt in juvenile delinquency determinations. ${ }^{50}$ But the Court's focus on the reasonable doubt standard blurred its former distinction between the burden of proof and the presumption of innocence established in Coffin. ${ }^{51}$ The opinion offers no discussion of the presumption other than to say that the reasonable doubt standard "provides concrete substance for the presumption of innocence"-a complete inversion of the Coffin opinion which stated that reasonable doubt was the result of the presumption of innocence. ${ }^{52}$ In addition, the Court stated that the burden of proof was essential to commanding respect in societies that value freedom and reputation. ${ }^{53}$

This, in effect, folded the presumption into the burden of proof, weakening the pretrial presumption of innocence. ${ }^{54}$ The Court only cited the Coffin opinion twice - first, to highlight that the burden of proof in criminal cases is beyond a reasonable doubt and second, that the reasonable doubt standard provides substances for the presumption of innocence. ${ }^{55}$ This holding began the transition of treating the presumption of innocence, not as its own substantive right, but as a procedural piece of the government's burden of proof. ${ }^{56}$

And the presumption of innocence became synonymous with the prosecutor's burden to prove an individual guilty beyond a reasonable doubt. Thus, the maxim of "innocent until proven guilty" signified that jurors convict only when there was enough proof that the crime was committed. It lost its greater meaning that the defendant was protected against any inferences or findings of guilt before trial. This change opened the way for judges to make legal examinations of defendants' guilt pretrial, where previously due process principles would not have allowed this. ${ }^{57}$

By placing the presumption of innocence within the burden of proof in criminal matters, the focus shifted to presumed innocence during trial and set the stage for lax pretrial protections ${ }^{58}{ }^{5}$ Therefore, the pretrial presumption of innocence, though

48. In re Winship, 397 U.S. at 359-60.

49. Id.

50. Id. at 359-61.

51. Baradaran, supra note 2 , at 736-37.

52. In re Winship, 397 U.S. at 363; Coffin v. United States, 156 U.S. 432, 460 (1895).

53. In re Winship, 397 U.S. at 363-64.

54. Baradaran, supra note 2, at 737.

55. In re Winship, 397 U.S. at 362-63.

56. Id. at 363; Baradaran, supra note 2, at 737.

57. Baradaran, supra note 2, at 738.

58. Id. 
still in existence, was substantially overlooked and weakened as a result. ${ }^{59}$

\section{The Burden of Proof Beyond a Reasonable Doubt}

The presumption of innocence necessarily requires a burden of proof of guilt to be placed on the accuser. ${ }^{60}$ Supreme Court jurisprudence continued to focus on and develop the burden of proof standard while omitting discussion of the presumption of innocence. ${ }^{61}$ This omission, in effect, continuously diminished the presumption of innocence. What was once a strong, substantive right became something that no longer needed to be addressed because it was encompassed within the burden of proof. ${ }^{62}$ The emphasis on the burden of proof in the Court's opinions folded the presumption of innocence into the reasonable doubt standard which became the main principle for protecting a criminal defendant's rights.

In Mullaney v. Wilbur, the Supreme Court invalidated a Maine statute that placed on the defendant the burden of proof that he acted in a heat of passion on sudden provocation. ${ }^{63}$ The Court found that to satisfy the Due Process Clause of the Fourteenth Amendment, the prosecution must show beyond a reasonable doubt the absence of heat of passion on sudden provocation. ${ }^{64}$ At common law, the defendant was required to carry this burden by a preponderance of the evidence. ${ }^{65}$ However, a trend led a majority of states to abandon that approach and require the prosecutor to establish the burden beyond a reasonable doubt. ${ }^{66}$ The Court reasoned: "The result, in a case such as this one where the defendant is required to prove the critical fact in dispute, is to increase further the likelihood of an erroneous murder conviction." ${ }^{97}$ Placing the burden on the prosecution reduces the margin of error in sentencing a defendant for a more serious crime than the one actually committed. ${ }^{68}$

In Patterson v. New York, the Court upheld placing the burden of proving extreme emotional disturbance, as an affirmative defense, by a preponderance of the evidence on the defendant. ${ }^{69}$ The Court distinguished Mullaney by describing the burden shifting in Mullaney required the defendant to disprove an essential fact regarding malice aforethought whereas, in Patterson, extreme emotional disturbance was not connected to an element of the crime of murder under New York law because it was an affirmative defense. ${ }^{70}$ These cases emphasize the

59. Id.

60. Coffin v. United States, 156 U.S. 432, 459 (1895).

61. See generally Patterson v. New York, 432 U.S. 197 (1977); Mullaney v. Wilbur, 421 U.S. 684 (1975).

62. Quintard-Morenas, supra note 3, at 143.

63. 421 U.S. at 704.

64. Id.

65. Id. at 694.

66. Id. at 696 .

67. Id. at 701 .

68. Id.

69. 432 U.S. 197, 201 (1977).

70. Id. (explaining New York's murder statute did not include malice aforethought as an 
necessity of keeping the burden of proof in criminal matters with the prosecution. Even in Patterson, the burden placed on the defendant to prove his own defense was a lower, preponderance of the evidence standard, and the defense was not an element of the crime. ${ }^{71}$

The presumption of innocence is the foundation for the burden of proof beyond a reasonable doubt - the substance giving strength to the standard of proof. $^{72}$ Further demise of the presumption could lead to weakening the basis for the burden of proof. ${ }^{73}$ Pretrial publicity tends to cause bias against a defendant, increasing the possibility of a tainted jury pool. ${ }^{74} \mathrm{~A}$ jury biased against the defendant defeats the structure of our criminal system because preconceived notions weaken the standard of beyond a reasonable doubt - the burden is easy when the jury already thinks the defendant is guilty. ${ }^{75}$ Operating under this "presumption of guilt" would force the system to shift the burden of proof onto the defense. Defendants would be required to prove their innocence, likely to the lower standard of a preponderance of the evidence as in civil court, destroying the structural distinction and higher burdens of criminal law. ${ }^{76}$ As the Court noted in Mullaney, this would lead to an increase in erroneous convictions. ${ }^{77}$

There is always in litigation a margin of error, representing error in fact finding, which both parties must take into account. Where one party has at stake an interest of transcending value - as a criminal defendant his liberty - this margin of error is reduced as to him by the process of placing on the other party the burden of . . persuading the factfinder at the conclusion of the trial of his guilt beyond a reasonable doubt. Due process commands that no man shall lose his liberty unless the Government has borne the burden of . . convincing the factfinder of his guilt. ${ }^{78}$

Though it is most unlikely that American criminal law will ever explicitly adopt these shifting burdens, the stage has been set due to the Supreme Court's presumption of innocence jurisprudence and the sensationalized nature of modern pretrial media coverage. Measures must be taken to prevent wrongful convictions by strengthening the substance for our criminal system.

\section{A Procedural Tool for the Jury}

Within the same decade as In re Winship, the Court reinforced the

element of the crime).

71. Id

72. Coffin v. United States, 156 U.S. 432, 460 (1895).

73. See id. at 432 .

74. Judy, supra note 8 , at 582 .

75. See id. at 568-572.

76. See Coffin, 156 U.S. at 432.

77. Mullaney v. Wilbur, 421 U.S. 684, 701 (1975).

78. In re Winship, 397 U.S. 358, 364 (1970) (quoting Speiser v. Randall, 357 U.S. 513 (1958)). 
presumption of innocence in trial. ${ }^{79}$ In Taylor v. Kentucky, petitioner appealed his robbery conviction arguing that he was entitled to a jury instruction on the presumption of innocence in addition to the provided instruction on the burden of proof beyond a reasonable doubt. ${ }^{80}$ The Supreme Court held a trial court's denial to give a requested instruction on the presumption of innocence was a violation of the Due Process Clause of the Fourteenth Amendment. ${ }^{81}$ Though the presumption of innocence is not found in the Constitution, the Court held that it is "a basic component of a fair trial under our system of criminal justice." 82 The Court noted scholarly criticism of the Coffin holding, which held the presumption of innocence and doctrine of reasonable doubt were distinct. ${ }^{83}$ One such critic, Harvard Law professor James Bradley Thayer, argued that the presumption of innocence was a way to describe the prosecution's duty to prove the defendant's guilt beyond a reasonable doubt and present evidence of such guilt. ${ }^{84}$ However, these scholars favored providing an instruction on the presumption of innocence, even when it was fully explained within an instruction on the burden of proof beyond a reasonable doubt, because of the effect on lay jurors. ${ }^{85}$

The Court emphasized that citizens, in contrast to legal scholars, may not understand the similarities between the presumption of innocence and the burden of proof beyond a reasonable doubt, and citizens could possibly gather additional insight from a separate instruction on the presumption of innocence. ${ }^{86}$

In a criminal case the term [presumption of innocence] does convey a special and perhaps useful hint over and above the other form of the rule about the burden of proof, in that it cautions the jury to put away from their minds all the suspicion that arises from the arrest, the indictment, and the arraignment, and to reach their conclusion solely from the legal evidence adduced. ${ }^{87}$

The Court remarked that an instruction on the presumption of innocence reminds the jury that they are to consider "nothing but the evidence" in their deliberations. ${ }^{88}$ The Court adopted this view and reversed the defendant's conviction for violating his Fourteenth Amendment right to a fair trial by refusing to provide an instruction on the presumption of innocence. ${ }^{89}$ Justice Stevens and Justice Rehnquist dissented, arguing that the function of an instruction on the presumption of innocence "is to make it clear that the burden of persuasion rests

79. See generally Taylor v. Kentucky, 436 U.S. 478 (1978).

80. Id. at 479 .

81. Id. at 490 .

82. Id. at 479 .

83. Id. at 483-84.

84. Id. at 483 n.12; Quintard-Morenas, supra note 3, at 123.

85. Taylor, 436 U.S. at 484.

86. Id.

87. Id. at 484-85.

88. Id. at 485-86.

89. Id. at 490 . 
entirely on the prosecutor." ${ }^{90}$ They believed an instruction on the burden of proof beyond a reasonable doubt served an identical function. ${ }^{91}$

Combining the burden of proof and presumption of innocence diffused the strength of the presumption. ${ }^{92}$ John Henry Wigmore wrote that the presumption of innocence was merely another expression that the burden of proof rested on the prosecution. ${ }^{93}$ Twentieth-century courts generally agreed that the presumption was a procedural right rather than substantive, and the definition of the presumption became nearly synonymous with the criminal burden of proof. ${ }^{94}$ After Coffin, the Court's view in In re Winship and Taylor shifted to a view that the presumption of innocence was merely an expression that the prosecution had the burden of proof beyond a reasonable doubt. ${ }^{95}$ Wedding the presumption and burden of proof caused a weakening in the enforcement of the presumption in pretrial matters. ${ }^{96}$ As Supreme Court jurisprudence relating to the presumption of innocence moved away from the Coffin opinion, protection of the presumption became increasingly relaxed and allowed the media more leeway to intrude on the rights of those accused of criminal offenses. ${ }^{97}$

To combat these effects, this Note argues that the Supreme Court should reinstate its holding in Coffin that the presumption of innocence is distinct and separate from the burden of proof, thereby reinforcing its importance as a substantive right of criminal defendants.

\section{Changes in the CRiminal Justice System}

In addition to Supreme Court jurisprudence, changes to the criminal justice system have also played a role in weakening the presumption of innocence. ${ }^{98}$ Traditionally, the presumption of innocence and due process generally provided for bail in all non-capital cases." "To deny bail to a person who is later determined to be innocent was thought to be far worse than the smaller risk posed to the public by releasing the accused." ${ }^{\prime 100}$ However in 1944, Rule 46 of the Federal Rules of Criminal Procedure provided factors that a judge could consider in determining whether to permit bail, which later allowed for an expansion of pretrial guilt determinations before trial by jury. ${ }^{101}$ Included in these considerations was "the weight of the evidence" against the

90. Id. at 491 (Stevens, J., dissenting).

91. Id.

92. Baradaran, supra note 2, at 737-38.

93. Quintard-Morenas, supra note 3, at 143.

94. Id.

95. Baradaran, supra note 2, at 741-42.

96. Quintard-Morenas, supra note 3, at 143-44.

97. Baradaran, supra note 2, at 742 .

98. Id. at 728-31.

99. Id. at 728 .

100. Id. at 729 .

101. Id. at 731 . 
defendant - something not previously considered by judges in the pretrial stage. ${ }^{102}$ Though this measure was initially limited to discovering whether a defendant would appear in court for trial if released, it was greatly expanded to allow judges to determine the likelihood of guilt before trial, eroding the presumption of innocence. ${ }^{103}$

During the crime control era of the 1960 s to the 1980 s, changes in bail determination allowed judges to weigh evidence and consider a defendant's threat to public safety, granting broader discretion in allowing judges to determine guilt pretrial. ${ }^{104}$ Rule 46 instructs that 18 U.S.C. $\S 3142$, also known as the Bail Reform Act of 1984, governs pretrial release. ${ }^{105}$ The Bail Reform Act of 1984 allows judges to consider a defendant's dangerousness to the community and potential recidivism. ${ }^{106}$ The Act is still in effect today and requires judges, upon determining release of a defendant, to consider the following: (1) the nature of the offense charged, (2) the weight of the evidence against the person, (3) the history and characteristics of the person, including criminal history and whether the person was on probation, parole, or release pending court proceedings, and (4) the nature and seriousness of the danger posed to a person or the community upon the person's release. ${ }^{107}$ Traditionally, the presumption of innocence and due process barred these considerations because guilt was to be determined at trial and not beforehand. ${ }^{108}$

The constitutionality of the Bail Reform Act was challenged in United States v. Salerno. ${ }^{109}$ The Act allows the pretrial detention of a defendant if the government shows by clear and convincing evidence after a hearing that no release conditions "will reasonably assure ... the safety of any other person and the community." 110 The Court of Appeals for the Second Circuit held pretrial detention based on the likelihood that the defendant would commit future crime was "repugnant to the concept of substantive due process" and facially unconstitutional. ${ }^{111}$ But the Supreme Court reversed, holding the Act constitutional. ${ }^{112}$ Chief Justice Rehnquist, writing for the Court, described that the Act did not impose pretrial detention as punishment for future crimes not yet committed, but as a regulation to prevent danger to the community by recidivists-a legitimate government interest. ${ }^{113}$

Justice Marshall and Justice Brennan dissented and argued a provision of the

102. Id.

103. Id.

104. Id. at 739 .

105. FED. R. CRIM. P. 46(a).

106. Baradaran, supra note 2, at 748 .

107. 18 U.S.C. $\S 3142$ (g) (2012).

108. Baradaran, supra note 2, at 731 .

109. 481 U.S. 739 (1987).

110. Id. at 741 .

111. Id. at 744 .

112. Id. at 755 .

113. Id. at 747 . 
Act itself stated that nothing in the Act could "be construed as modifying or limiting the presumption of innocence." ${ }^{114}$ The dissenters found the current Act to be facially unconstitutional and explained the majority's conclusion was a denial of the role of the Eighth Amendment's Excessive Bail Clause and the Due Process Clause in protecting the presumption of innocence. ${ }^{115}$ "But at the end of the day the presumption of innocence protects the innocent; the shortcuts we take with those whom we believe to be guilty injure only those wrongfully accused and, ultimately, ourselves." 116

These changes in the criminal bail system allowing pretrial consideration of guilt, paired with a loosening of Supreme Court jurisprudence, have further eroded the presumption of innocence by altering the purpose of bail determinations from ensuring that defendants appear in court to preventing defendants from committing further crime before guilt determinations. ${ }^{117}$ In effect, judges are making determinations of guilt by considering just how dangerous a defendant is before a jury determines his guilt or innocence. ${ }^{118}$ This result was largely caused by Supreme Court jurisprudence that blurred the line between the presumption of innocence and burden of proof, allowing greater leeway in pretrial guilt determination; changes in bail reform monopolized on this unclear ground through practices embodied in the Bail Reform Act. ${ }^{119}$ " [L]egal scholars . . a across the Atlantic lost sight, somewhat purposely, of the presumption of innocence as a shield against punishment, concerned that an expansion of the doctrine beyond the courtroom would undermine the fight against crime." ${ }^{, 120}$ And the press followed suit, reporting on pretrial matters like bail determinations, perp walks, and mug shots, which further erodes a defendant's presumption of innocence. ${ }^{121}$ The combination of changes in the criminal system paved the way for members of the press to take liberties in reporting on crime, creating significant repercussions for defendants.

\section{Impact of Pretrial Media Coverage}

The First Amendment prohibits "abridging the freedom of speech, or of the press." 122 The Sixth Amendment guarantees "trial, by an impartial jury" in federal criminal cases, which the Fourteenth Amendment extends to state criminal trials through the Due Process Clause. ${ }^{123}$ The conflict between these amendments is where this analysis begins to determine how to balance the rights encompassed by each without infringing upon those of the other.

114. Id. at 762-63 (Marshall, J., dissenting).

115. Id.

116. Id. at 767 .

117. Baradaran, supra note 2, at 733 .

118. Id. at 731,748 .

119. Id. at 738 .

120. Quintard-Morenas, supra note 3, at 109.

121. Gillian \& Iyengar, supra note 6; YANICH, supra note 6, at 33-34.

122. U.S. CONST. amend. I.

123. Neb. Press Ass'n v. Stuart, 427 U.S. 539, 551 (1976). 


\section{A. First Amendment Jurisprudence and Freedom of the Press}

The First Amendment provides "Congress shall make no law . . . abridging the freedom of speech, or of the press." "24 The press is "the only organized private business that is given explicit constitutional protection." ${ }^{125}$ Some argue the Supreme Court's First Amendment jurisprudence has allowed the press leeway to conduct "bad journalism" that abandons its traditional purpose of informing the public about stories that sensationalize and entertain. ${ }^{126}$ For example, the Court defers to the media on statements of opinion-only misrepresentations of fact serve as grounds for liability in a libel action. ${ }^{127}$ This, in turn, encourages the media to stray from fact to avoid liability, providing a platform for television news anchors to discuss a defendant's guilt or innocence with expert attorneys who provide their opinions as to a defendant's guilt or innocence. ${ }^{128}$ "Beyond avoiding acting with actual malice with regard to public figures and refraining from intentionally ..., recklessly, or negligently defaming private individuals, [the] media has no legal responsibility to fully and accurately report the truth."129 This allows the media to spread "inaccurate and incomplete stories" that affect legal proceedings. ${ }^{130}$

\section{B. Changing Nature of News Media}

United States Supreme Court Justices Louis Brandeis and Earl Warren cautioned that technological advancements - in their time, the telegraph and telephone-would require courts to modify Fourth Amendment analysis to maintain a protection of privacy. ${ }^{131}$ Modern technology has progressed extensively since that time, with the advent of the Internet and smartphones, globalizing instant communication. ${ }^{132}$ Information is rapidly shared, creating a growing risk of juror contamination. ${ }^{133}$

124. U.S. CONST. amend. I.

125. Potter Stewart, Or of the Press, 26 Hastings L.J. 631, 633 (1975) ("Most of the other provisions in the Bill of Rights protect specific liberties or specific rights of individuals . . . In contrast, the Free Press Clause extends protection to an institution.").

126. Judy, supra note 8, at 547-49.

127. Nat'l Ass'n of Letter Carriers v. Austin, 418 U.S. 264, 285-86 (1974); Judy, supra note 8 , at 559 .

128. Judy, supra note 8, at 560; Andrea D. Lyon, Criminal Coverage: News Media, Legal Commentary, and the Crucible of the Presumption of Innocence, 1 ReYNOLds CT. \& Media L.J. 427, 441-42 (2011).

129. Judy, supra note 8, at 561-62.

130. Id. at 562 .

131. Matthew Mastromauro, Pretrial Prejudice 2.0: How YouTube Generated News Coverage Is Set to Complicate the Concepts of Pretrial Prejudice Doctrine and Endanger Sixth Amendment Fair Trial Rights, 10 J. High TECH. L. 289, 289 (2010).

132. Id.

133. Id. at 336 . 
Additionally, changes in the nature of U.S. news media with twenty-fourhour news coverage have made it more difficult to keep extrajudicial prejudice from entering the jury box. ${ }^{134}$ Between 1996 and 1997, eighty-three percent of Los Angeles local television news stories were about violent crime. ${ }^{135}$ A study of Baltimore and Philadelphia local news stations in 1998 revealed that crime stories were the most covered format. ${ }^{136}$ Crime news is useful to local news stations because of the low cost of obtaining credible information from police stations and the dramatic value that attracts viewers to the story. ${ }^{137}$ The expansion of programming - such as twenty-four-hour news coverage, daily talk shows, and online media forums - has further amplified the need for crime news to fill airtime with dramatic value. ${ }^{138}$

Numerous studies have shown that a connection exists between the amount of pretrial publicity and the likelihood a person knows about a particular case. ${ }^{139}$ These studies conclude that a person is more likely to form a biased opinion about the defendant the more that they are exposed to information about the defendant's case. ${ }^{140}$ Although ideological backgrounds have a certain impact, these studies found the pretrial media coverage is "the most serious cause" of juror bias. ${ }^{141}$ This is a problem because the media can disseminate opinions and inaccuracies without liability, leading the public to believe that such assertions are factual information. ${ }^{142}$ Further, crime news is misleading; it suggests that a majority of crime is violent crime and falsely magnifies the occurrence of violent crime. ${ }^{143}$ For example, murder accounted for less than one percent of Los Angeles crime between 1996 and 1997, but the number of murder stories alone equaled the total number of nonviolent crime stories. ${ }^{144}$ The enlargement of crime news from print sources to digital media has caused facts to be mixed with speculation, muddling news and entertainment. ${ }^{145}$

\section{Positive Consequences of Pretrial Publicity}

Despite the negative consequences associated with pretrial publicity, there are certain limited benefits that arise from pretrial media coverage. Broadcasted coverage of the criminal justice system promotes public education, deterrence,

134. Id.

135. Gillian \& Iyengar, supra note 6 , at 562.

136. YANICH, supra note 6, at 33-34.

137. Vincent F. Sacco, Media Constructions of Crime, 539 Am. ACAD. Pol. Soc. Sci. 141, 144 (1995).

138. Id. at 145 .

139. Constantini \& King, supra note 7, at 11.

140. Id. at 17-24.

141. Id. at 36-38.

142. Nat'l Ass'n of Letter Carriers v. Austin, 418 U.S. 264, 285-86 (1974); Judy, supra note 8 , at 559 .

143. Sacco, supra note 137, at 143.

144. Breheny \& Kelly, supra note 32, at 381; Gillian \& Iyengar, supra note 6, at 562.

145. Sacco, supra note 137 , at 145. 
and freedom of the press. ${ }^{146}$ During the 1980 s, courts expanded the use of cameras in the courtroom to educate the public on the justice system and reassure citizens that justice was being served. ${ }^{147}$ Pretrial coverage highlights the consequences of crime with images of handcuffs, mug shots, imprisonment, life sentences, and a tough-on-crime mentality. ${ }^{148} \mathrm{~A}$ study revealed that only four days following news reports of life sentences or capital punishment for violent offenses, the number of reported homicides decreased substantially. ${ }^{149}$ Further, pretrial publicity promotes the First Amendment freedom of the press, which serves a whistle-blowing function to check abuses of authority by public officials, police, and others in power. ${ }^{150}$ The Supreme Court has often expressed that " $[t]$ he free press has been a mighty catalyst in awakening public interest in governmental affairs, exposing corruption among public officers and employees and generally informing the citizenry of public events and occurrences, including court proceedings." " ${ }^{151}$ But the Court acknowledged that such exercise must be subject to maintaining a fair judicial process. ${ }^{152}$

\section{Negative Consequences of Pretrial Publicity}

There are two major negative impacts for defendants whose cases receive media attention: (1) jury contamination and (2) reinforced negative attitudes of the public toward defendants through criminal labeling. ${ }^{153}$

The greatest risk of pretrial news coverage is depriving a defendant of his constitutional rights by allowing a prejudiced jury to proceed, thereby denying his right to due process and a fair trial. ${ }^{154}$ A 1997 study polling potential jurors in areas where a large trial was expected revealed that a majority of the jury pool knew the facts of the case prior to a large trial and sided with the prosecution as a result. ${ }^{155}$ Despite the fact that the burden of proof beyond a reasonable doubt standard is supposed to decrease the margin of error in erroneous convictions, innocent people are convicted for crimes that they did not commit. ${ }^{156}$ The Innocence Project, an organization dedicated to exonerating those wrongfully

146. Susanna R. Barber, Televised Trials: Weighing Advantages Against Disadvantages, 10 Just. SYST. J. 279, 280-81 (1985).

147. Id. at 280 .

148. Id. at 281 .

149. Id.

150. Judy, supra note 8, at 549.

151. Leathers v. Medlock, 499 U.S. 439, 446 (1991); Estes v. Texas, 381 U.S. 532, 539 (1965)

152. Estes, 381 U.S. at 539.

153. Barber, supra note 146, at 282.

154. Mastromauro, supra note 131, at 308.

155. Id. at 318 .

156. In re Winship, 397 U.S. 358, 364 (1970) (quoting Speiser v. Randall, 357 U.S. 513 (1958)); DNA Exonerations Nationwide, InNOCENCE Project (Feb. 19, 2016, 4:46 PM), http://www.innocenceproject.org/free-innocent/improve-the-law/fact-sheets/dna-exonerationsnationwide [https://perma.cc/D24E-DL33]. 
convicted through DNA testing, reported that 337 people were later exonerated by DNA evidence after being wrongly convicted, and the actual perpetrator was found in 166 of those cases and convicted in 146 cases. ${ }^{157}$ Those wrongfully convicted were incarcerated for an average of fourteen years. ${ }^{158}$ Damon Thibodeaux spent fifteen years on death row in solitary confinement before he was exonerated in September 2012. ${ }^{159}$ The twenty-two-year-old was wrongfully convicted of murder by a Louisiana court though there was no physical evidence connecting him to the crime. ${ }^{160}$ Thibodeaux gave a confession that was inconsistent with the crime after a nine-hour interrogation, only fifty-four minutes of which were recorded. ${ }^{161}$ The two eyewitnesses, who identified Thibodeaux from a photo array as the person they saw at the crime scene, saw Thibodeaux's picture in the news as a suspect before they participated in the investigation. ${ }^{162}$ Upon reinvestigation, DNA evidence from the murder weapon revealed male DNA that did not belong to Thibodeaux. ${ }^{163}$ Misidentification by witnesses is the leading cause of wrongful convictions and has been present in seventy-two percent of exonerated cases. ${ }^{164}$

Pretrial coverage also has lasting consequences for a defendant in terms of public ridicule and lack of privacy. ${ }^{165}$ "Television exposure is a form of public punishment, leading to permanent stigmatization in the eyes of the community; even if a defendant is acquitted ...." ${ }^{\prime 166}$ Even if a defendant manages to receive a fair trial, despite extensive media coverage of her case, her presumption of innocence means nothing to an outraged public. ${ }^{167}$ Casey Anthony, a Florida woman, was charged with the murder of her two-year-old daughter, Caylee. ${ }^{168}$ Anthony's case received constant media attention due to the scandalous nature of the "mother kills child" scenario, and the media released photos of Anthony partying and drinking with friends during the time her daughter was reported missing. ${ }^{169}$ Despite her acquittal, Anthony had to be flown to an undisclosed location because of the mob of citizens waiting for her on the courthouse steps. ${ }^{170}$

157. DNA Exonerations Nationwide, supra note 156.

158. Id.

159. The Cases: Damon Thibodeaux, INNOCENCE PROJECT, http://www.innocenceproject.org/ cases-false-imprisonment/damon-thibodeaux (last visited Apr. 7, 2017) [https://perma.cc/ZU2ATGFW].

160. Id.

161. Id.

162. Id.

163. Id.

164. The Causes of Wrongful Conviction, INNOCENCE PROJECT, http://www.innocenceproject. org/causes-wrongful-conviction (last visited Apr. 7, 2017) [https://perma.cc/359A-BL54].

165. Barber, supra note 146, at 282.

166. Id.

167. Lyon, supra note 128 , at 429-30.

168. Id. at 428-30.

169. Id. at 430 .

170. Christina Ng, Casey Anthony Says She Lives 'Off the Kindness of Others,' ABC NEws 
In the aftermath of the trial, she was listed as the most hated person in the United States and has remained in hiding since her acquittal. ${ }^{171}$

In March 2013, two years after her acquittal, Anthony came out of hiding to attend a bankruptcy hearing and was greeted by a media swarm. ${ }^{172}$ Cheney Mason, one of Anthony's lawyers who remains in contact with her today said, "She hasn't been freed from her incarceration yet [because] she can't go out[,] . . . she can't go shopping[,] . . . she can't even go to McDonald's. She can't do anything." the most hated woman in the world, according to some media outlets, to being a normal person or being able to live a normal life." ${ }^{174}$ Andrea Lyon, who served as part of Anthony's defense team, was physically assaulted while working on the case and continued to receive hate mail in the years following Anthony's acquittal. ${ }^{175}$

Those accused of crime are not the only ones burdened by pretrial publicity; media coverage of crime stories is misleading and causes an increased public fear of victimization by over-reporting violent crime. ${ }^{176}$ Pretrial media coverage mixes fact and speculation. ${ }^{177}$ It distorts the reality that most crime is nonviolent. ${ }^{178}$ The issue with the media's focus on and presentation of pretrial publicity is that it affects the jury pool by setting the stage for bias against the defendant, thereby jeopardizing a defendant's constitutional guarantee to have a fair trial. ${ }^{179}$ Clarence Darrow once said:

Trial by jury is rapidly being destroyed in America by the manner in which the newspapers handle all sensational cases .... As the law stands today there is no important criminal case where the newspapers are not guilty of contempt of court day after day. ${ }^{180}$

The issue is that in the face of incessant pretrial coverage furthered by today's instant transmission of news coverage, the courts have no adequate means to limit pretrial publicity. ${ }^{181}$ By examining measures currently available to courts, we can determine what efforts must be made to allow the judiciary to protect the

(Mar. 4, 2013), http://abcnews.go.com/US/casey-anthony-publicly-grilled-time-lives-offkindness/story?id=18647301 [https://perma.cc/6FXS-6TPA].

171. Id.

172. Jean Casarez, What Life Is Like for Casey Anthony, CNN (July 4, 2014, 11:53 AM), http://www.cnn.com/2014/07/03/justice/casey-anthony-today/ [https://perma.cc/8S74-FHH9].

173. Id.

174. $\mathrm{Ng}$, supra note 170 .

175. Lyon, supra note 128 , at 430.

176. Sacco, supra note 137 , at 143.

177. Id. at 145 .

178. Id. at 143 .

179. Judy, supra note 8, at 548 .

180. Id. at 588-89 (internal quotations omitted) (quoting Stuart H. Perry, The Courts, The Press, and the Public, 30 Mich. L. ReV. 228, 234 (1931)).

181. Id. at $570-71$. 
presumption of innocence while balancing the freedom of the press.

\section{Current Methods to Shield the Presumption}

Because of the Supreme Court's freedom of the press jurisprudence and the First Amendment, it is incredibly difficult to limit the press's pretrial media coverage. ${ }^{182}$ In Sheppard v. Maxwell, the Court outlined the following alternatives to restraining freedom of the press: (a) gag orders, (b) changes of venue, (c) continuance of trial until publicity subsides, and (d) clear and emphatic jury instructions on a juror's duty to render a decision based on evidence presented in court. ${ }^{183}$ The Court stated, "Given the pervasiveness of modern communications and the difficulty of effacing prejudicial publicity from the minds of the jurors, the trial courts must take strong measures to ensure that the balance is never weighed against the accused." 184 Yet methods currently available to courts are largely ineffective and weigh against the accused. ${ }^{185}$

In this Section, this Note will discuss three traditional methods used by the courts to limit prejudicial pretrial publicity: gag orders, changes of venue, and sealing courtrooms. This Note will use Indiana law to highlight the standards necessary to obtain these orders, and it will discuss Supreme Court jurisprudence to illustrate how each order inadequately shields the presumption of innocence from pretrial publicity.

\section{A. Gag Orders}

A gag order is an injunction against speech, granted by a court to prevent certain parties from discussing a case. ${ }^{186}$ In Indiana, the standard required for a court to issue a gag order for pretrial publicity is "a reasonable likelihood that pretrial publicity will prejudice a fair trial." 187 To determine whether a "reasonable likelihood" exists, the nature and extent of the pretrial publicity must be analyzed by the trial court. ${ }^{188}$ Before a gag order may be issued, a trial court must examine whether "alternate means would effectively mitigate the prejudicial effect of the pretrial publicity." 189

However, the U.S. Supreme Court held in Nebraska Press Ass' $n$ v. Stuart that a gag order cannot be issued against the media to prevent its coverage of open judicial proceedings due to the First Amendment freedom of the press. ${ }^{190}$ There, a gag order was issued barring all members of the press from publishing any

182. See generally Judy, supra note 8.

183. 384 U.S. 333, 357-63 (1966).

184. Id. at 362 .

185. Judy, supra note 8, at 570-71.

186. S. Bend Tribune v. Elkhart Circuit Court, 691 N.E.2d 200, 202 (Ind. Ct. App. 1998).

187. $I d$.

188. Id.

189. Id.

190. U.S. Const. amend. I; Neb. Press Ass'n v. Stuart, 427 U.S. 539, 570 (1976). 
details of the case, including information already in their possession. ${ }^{191}$ Despite the Court's acknowledgement that the freedom of the press is not an absolute right, it held a defendant has a "heavy burden" to overcome the presumption against the use of prior restraints against the media. ${ }^{192}$ The Court said, "Prior restraints on speech and publication are the most serious and the least tolerable infringement on First Amendment rights." 193 The Court further noted there is nothing that can prevent the press from reporting on events that occur in a public courtroom. ${ }^{194}$ These orders are rarely granted because of the difficulty in monitoring those to whom they apply. ${ }^{195}$ Because the media can still report on criminal proceedings, even when a gag order is issued, a gag order is an ineffective method of protecting the presumption of innocence. ${ }^{196}$

\section{B. Change of Venue}

To change venue in Indiana, a defendant must file a verified petition "alleging that bias or prejudice exists in the county." 197 The court will then hold a hearing to consider the petition. ${ }^{198}$ The defendant must produce evidence of bias or prejudice in the county such that the court is convinced that the defendant could not obtain a fair trial in that county. ${ }^{199}$ The defendant must show (1) the existence of prejudicial pretrial publicity and (2) the inability of jurors to set aside their preconceived notions of guilt and render an impartial verdict based on the evidence. ${ }^{200}$ Jury exposure to pretrial coverage is not enough to establish prejudice. ${ }^{201}$ Like a gag order, granting a change of venue is largely discretionary. ${ }^{202}$ In the digital age, permitting a change of venue has become an inadequate way to address and avoid the spread of pretrial prejudice due to technological advancements and extensive regional news coverage. ${ }^{203}$

In Groppi v. Wisconsin, the Supreme Court held unconstitutional a state statute that prohibited a change of venue in misdemeanor prosecutions. ${ }^{204}$ The Court described the Constitution requires that defendants have the opportunity to request a change of venue based on the Fourteenth Amendment right to an impartial jury. ${ }^{205}$ Further, in Rideau v. State of Louisiana the Court held denying

191. Neb. Press Ass'n, 427 U.S. at 541-43.

192. Id. at 570 .

193. Id. at 559 .

194. Id. at 568 (citing Sheppard v. Maxwell 384 U.S. 333, 362-63 (1966)).

195. Judy, supra note 8, at 571.

196. See Neb. Press Ass'n, 427 U.S. at 539.

197. IND. CODE $\S 35-36-6-1$ (2016).

198. Id.

199. Dorton v. State, 419 N.E.2d 1289 (Ind. 1981).

200. Collins v. State, 826 N.E.2d 671, 676 (Ind. Ct. App. 2005).

201. Id. at 676 .

202. Dorton, 419 N.E.2d at 1294.

203. Breheny \& Kelly, supra note 32 , at 390-91.

204. 400 U.S. 505, 506 (1971).

205. Id. at 510-11. 
a defendant's request for a change of venue was unconstitutional after the community had been repeatedly exposed to the defendant's videotaped confession during a police interview that ultimately led to his conviction. ${ }^{206}$ The Court determined that it was a violation of the defendant's due process rights to be subject to trial in a community that had witnessed this publicity. ${ }^{207}$

Changes of venue are, therefore, ineffective measures of shielding the presumption of innocence from pretrial publicity because prejudicial pretrial publicity must already exist before the change may be requested. ${ }^{208}$ Further, regional news coverage and social media defeat the ability of venue changes to escape the press by fleeing to the county next door. ${ }^{209}$

\section{Sealing the Court}

Finally, sealing or excluding the public from court is permitted under certain, limited circumstances. In Brown \& Williamson Tobacco Corp. v. Federal Trade Commission, the Supreme Court recognized there is a common law presumption that court proceedings and records are open to the public. ${ }^{210}$ In Indiana, a court may not exclude the public from any criminal proceeding unless "it first affords the parties and the general public a meaningful opportunity to be heard on the issue of any proposed exclusion." 211 If a party objects to a motion to exclude, the party who filed the motion or the court must prove by clear and convincing evidence that (1) disclosure of the proceeding's contents and the record would create a serious and imminent danger to the defendant's rights, (2) the prejudicial effect created by the disclosure cannot be avoided by reasonable alternative means, and (3) there is a substantial probability that the exclusion will effectively protect against the perceived harm. ${ }^{212}$ Any granted exclusion must not be extended further than as required by the circumstances and must be temporary. ${ }^{213}$ This standard makes it difficult to seal the court in criminal cases. Cases where the public is generally excluded from proceedings include matters involving minors, such as juvenile delinquency and adoptions. ${ }^{214}$

In Gannet Co., Inc. v. DePasquale, the Court held the public had no constitutional right under the Sixth and Fourteenth Amendments to attend a pretrial proceeding in a murder case when the judge, prosecutor, and defendant agreed to a closed proceeding. ${ }^{215}$ "Publicity concerning the proceedings at a pretrial hearing ... could influence public opinion against a defendant and inform potential jurors of inculpatory information wholly inadmissible at the actual

206. 373 U.S. 723, 724-25, 727 (1963).

207. Id. at 727 .

208. Collins v. State, 826 N.E.2d 671, 676 (Ind. Ct. App. 2005).

209. Breheny \& Kelly, supra note 32, at 390-91.

210. 710 F.2d 1165 (6th Cir. 1983).

211. IND. CODE $§ 5-14-2-3$ (2016).

212. Id. § 5-14-2-6.

213. Id.

214. Id. §§ 31-32-6-2, 31-19-19-1.

215. 443 U.S. 368, 370-71, 391 (1979). 
trial."216 The Court's recognition that pretrial publicity could be especially dangerous to a defendant because of the difficulty in measuring its effect on a fair trial caused it to give trial judges power to prevent and correct potentially negative consequences. ${ }^{217}$

The Court has long recognized that adverse publicity can endanger the ability of a defendant to receive a fair trial. To safeguard the due process rights of the accused, a trial judge has an affirmative constitutional duty to minimize the effects of prejudicial pretrial publicity. And because of the Constitution's pervasive concern for these due process rights, a trial judge may surely take protective measures even when they are not strictly and inescapably necessary. ${ }^{218}$

The Court emphasized that the purpose of the Sixth Amendment public trial guarantee is to benefit the defendant, not a public right to attend criminal trials. ${ }^{219}$

These measures exist because the Supreme Court has acknowledged through its jurisprudence that inaccurate pretrial coverage can cause potential damage to a defendant's case. ${ }^{220} \mathrm{Gag}$ orders, changes of venue, and sealing the court are ineffective measures to prevent pretrial publicity from infringing on a defendant's constitutional rights because of the limited use, high standards to achieve, and difficulty in enforcing the orders. ${ }^{221}$ Something more is needed to adequately provide courts with the measures needed to protect the presumption of innocence.

\section{New Proposals to Strengthen the Presumption of InNocence}

Within its freedom of the press jurisprudence, the Supreme Court has repeatedly stated that First Amendment rights are not absolute. ${ }^{222}$ Therefore, placing conservative limits on the freedom of the press in the scope of pretrial coverage would not unduly restrict the First Amendment rights of the media. This Section of this Note will introduce laws of England and France to demonstrate how foreign nations have responded to their own struggles with debilitating pretrial media coverage. Diverging from the judicial realm, these methods were actions taken by each country's respective lawmaking body in response to negative consequences of an unrestrained media. ${ }^{223}$ They now serve as tools used by their judicial officials to shield the presumption of innocence from pretrial publicity. This Note proposes that the U.S. government enact similar legislation.

216. Id. at 378 .

217. Id.

218. Id

219. Id. at $379-81$.

220. Judy, supra note 8, at 572 .

221. See generally IND. CODE § 5-14-2-6 (2016) (stating hearing procedural standards); Neb. Press Ass'n v. Stuart, 427 U.S. 539 (1976); Collins v. State, 826 N.E.2d 671, 675-76 (Ind. Ct. App. 2005).

222. Nebraska Press Ass'n, 427 U.S. at 570.

223. See infra Part VI.A-B. 


\section{A. Adopt Legislation Limiting Freedom of the Press in Criminal Matters}

Although England does not have a constitutional amendment, or even a constitution, to explicitly protect the freedom of the press, it does so through its common law. ${ }^{224}$ That common law protection is what the Framers used to draft our own version of protected speech: the First Amendment. ${ }^{225}$ Yet the British have long recognized that unrestrained media threatens the fair administration of justice, and the English Parliament enabled its judges to place limitations on the press's pretrial media coverage with its Contempt of Court Act of 1981. ${ }^{226}$

The Contempt of Court Act of 1981 assigns strict liability to a publication or televised program that "creates a substantial risk that the course of justice in the proceedings in question will be seriously impeded or prejudiced."227 To determine if the Act was violated, a court "consider[s] when the piece was published, the likelihood that jurors saw the piece, whether the piece affected the opinions of the jurors, and the likelihood that jury members will be able to follow directions aimed at neutralizing the prejudicial impact of the piece."228 Then the Court must "determine whether the risk of [such] prejudice... is both immediate and serious" before sanctioning members of the press. ${ }^{229}$

The Act only applies to active proceedings, and there is an exception for publications discussing, in good faith, matters of public affairs where a risk of prejudice would only be incidental. ${ }^{230}$ Another defense exists for publishing material without knowing that its publication is contemptuous. ${ }^{231}$ Although this "substantial risk" of prejudice standard might be viewed as an even higher burden than the Indiana standard for achieving a gag order, it applies directly to the press unlike gag orders, which are curtailed by the First Amendment freedom of the press. ${ }^{232}$ Further, it gives the judiciary adequate ability to monitor and deter the use of inflammatory pretrial publicity. ${ }^{233}$ The Act also allows liability for four other categories of contempt including "deliberate contempt, publication of information regarding jury deliberations, scandalous attacks on the judiciary, and

224. Judy, supra note 8 , at 589.

225. Id.

226. Mark J. Geragos, The Thirteenth Juror: Media Coverage of Supersized Trials, 39 LoY. L.A. L. REV. 1167, 1192-93 (2006).

227. Contempt of Court Act 1981, c. 49 (Eng.), http://www.legislation.gov.uk/ukpga/1981/ 49\#commentary-c810785 [https://perma.cc/ANP2-AZCM].

228. Geragos, supra note 226, at 1193.

229. Id. at 1194 (internal quotations omitted) (quoting Joanne Armstrong Brandwood, You Say "Fair Trial" and I Say "Free Press": British and American Approaches to Protecting Defendants' Rights in High Profile Trials, 75 N.Y.U. L. REV. 1412, 1430 (2000)).

230. Contempt of Court Act 1981, c. 49 (Eng.), http://www.legislation.gov.uk/ukpga/1981/ 49\#commentary-c810785 [https://perma.cc/ANP2-AZCM].

231. Judy, supra note 8 , at 590.

232. See generally S. Bend Tribune v. Elkhart Circuit Court, 691 N.E.2d 200 (Ind. Ct. App. 1998) (describing gag orders do not apply to the parties but not the press).

233. See generally Judy, supra note 8, at 589-92. 
disobedience of a direct order of the court." ${ }^{, 34}$ Under the Contempt of Court Act, information about a defendant's character, past record, or opinions expressed as to the defendant's guilt would violate the Act. ${ }^{235}$ Violators of the Act may be imprisoned up to two years and fined up to 2500 pounds (approximately $\$ 3040){ }^{236}$

\section{B. Make the Presumption of Innocence an Explicit Right}

In France, the presumption of innocence is a personal right that is not limited to criminal law but included in the French Civil Code. ${ }^{237}$ France was heavily criticized in the aftermath of the French Revolution for its ambivalence to the presumption of innocence. ${ }^{238}$ Though included in Article 9 of the French Declaration of Rights of 1789 , the presumption of innocence was overlooked. ${ }^{239}$ King Louis XVI was publicly labeled a tyrant in revolutionary pamphlets. ${ }^{240}$ Tried without the presumption of innocence, he was swiftly convicted and executed. ${ }^{241}$ International criticism continued post-revolution when the trials of suspect antirevolutionists were held in Orleans, France; the accused were punished before their matters were brought before the judges. ${ }^{242}$ In 1793, the Law of Suspects allowed persons whose "conduct, associations, comments or writings acted as enemies of liberty" to be detained. ${ }^{243}$ Under this law, those who had been acquitted could be held indefinitely, as suspects. ${ }^{244}$ The disparity between one accused of a crime and one convicted of a crime was abolished; in France, to be suspected of a crime was to be guilty. ${ }^{245}$

Nearly two centuries of mistreatment ensued until the year 2000, when changes were implemented in response to a commission report by the European Court of Human Rights. ${ }^{246}$ Included in these changes was the creation of the presumption of innocence as a personal right, not only for those charged with a crime, but for anyone under investigation. ${ }^{247}$ This right is now included in the French Code of Criminal Procedure and requires that evidence collected by

234. Id. at 589-90.

235. Susan Hanley Duncan, Pretrial Publicity in High Profile Trials: An Integrated Approach to Protecting the Right to a Fair Trial and the Right to Privacy, 34 OHIO N.U. L. REV. 755, 775 (2008).

236. Contempt of Court Act 1981, c. 49 (Eng.), http://www.legislation.gov.uk/ukpga/1981/ 49\#commentary-c810785 [https://perma.cc/ANP2-AZCM].

237. Quintard-Morenas, supra note 3, at 137-138.

238. Id. at 133-34.

239. Id. at 133 .

240. Id. at 134 .

241. Id.

242. $I d$.

243. Id.

244. Id. at 134-35.

245. Id. at 134 .

246. Id. at 138-39.

247. Id. at 138 . 
judges, who take part in investigations, include evidence of innocence and guilt. ${ }^{248}$ In addition, prosecutors are obligated to collect and present evidence of a defendant's guilt and innocence, and the defendant is not required to produce any evidence. ${ }^{249}$ Further emphasis of the right to a presumption of innocence is evident in rules applying to media coverage and jurors: "All necessary measures must be taken to prevent a person handcuffed or shackled from being photographed or filmed. Jurors must swear 'to betray neither the interests of the accused nor those of society' and 'to remember that the accused is presumed innocent. " ${ }^{250}$ Additionally, the presumption is extended in civil matters. ${ }^{251}$ The French Civil Code protects defendants from being "publically described as guilty before conviction" 252 and allows the court to take any measure "to put an end to the infringement of the presumption of innocence." 253 Members of the press are barred from implying that a person allegedly involved in a crime is guilty and the word "murderer" cannot be used in printed media to describe a suspect. ${ }^{254}$

France, like the United States, values liberty and individual freedom of expression. Article XI of France's Declaration of Rights is the French equivalent of the First Amendment freedom of speech in its ardent protection of spoken and written communication of its citizens, including the press. ${ }^{255}$ The text of Article XI reads: "The unrestrained communication of thoughts and opinions being one of the most precious rights of man, every citizen may speak, write, and publish freely, provided he is responsible for the abuse of this liberty, in cases determined by law." ${ }^{256}$ Unlike the First Amendment, France's Article XI contains broad language written into the text that provides notice of the limited nature of this right, so that the press does not abuse this protection. ${ }^{257}$

France and England alike have acknowledged through lawmaking that the freedom of expression and communication afforded to the press is precious, but

248. Id. at 139 .

249. E. Aguilera, Ministère de la Justice: The French Legal System 10 (2012), www.justice.gouv.fr/art_pix/french_legal_system.pdf [https://perma.cc/7VMM-EA4A].

250. Quintard-Morenas, supra note 3 , at 139 (quoting CODE DE PROCÉDURE PÉNALE [C. PR. PÉn.] [Criminal Procedure Code] art. 304 (Fr.)).

251. Id. at 140 .

252. Id.

253. Code Civil [C. CIV.] [CIVIL CODE] art. 9-1 (Fr.), https://www.legifrance.gouv.fr/ affichCodeArticle.do?cidTexte=LEGITEXT000006070721\&idArticle=LEGIARTI000006419316 [https://perma.cc/ZZ5W-MP98]; Georges Rouhette \& AnNe RouhetTe-Berton, Civil CodE 1-2 (2006), translated at https://www.legifrance.gouv.fr/content/download/1950/13681/version/ 3/.../Code_22.pdf [https://perma.cc/JVG9-MJHC].

254. Quintard-Morenas, supra note 3, at 141.

255. Declaration of the Rights of Man and of the Citizen, 1789, art. Xi (Fr.), http://www.constitutionnet.org/files/declaration_of_the_rights_of_man_1789.pdf [https://perma.cc/EK7B-9C9Y].

256. Id.

257. Id.; see also U.S. CONST. amend. I. 
not unlimited. ${ }^{258}$ So, too, has the U.S. Supreme Court in its recognition that the First Amendment is not absolute. ${ }^{259}$ The difference is that we have yet to act, as these countries have done, in ensuring that the limits of this freedom are codified to prohibit abuse at the cost of a defendant's constitutional rights. In addition to my recommendation that the U.S. criminal justice system reinstate the holding in Coffin, that the presumption of innocence is distinct and separate from the burden of proof, ${ }^{260}$ this Note recommends that the federal government (1) adopt legislation limiting freedom of the press in criminal matters, and (2) make the presumption of innocence an explicit right. These measures will provide the judicial branch with adequate tools to ensure that the presumption of innocence and freedom of the press are rebalanced.

\section{CONCLUSION}

Both freedom of the press and the presumption of innocence are imperative to democracy in that the former maintains an informed public and the latter protects the rights of the accused. ${ }^{261}$ But when one is protected to the extent that the other is diminished, action must be taken to rebalance these protections. ${ }^{262}$ Chief Justice Burger, writing for the majority in Nebraska Press Ass'n, wrote the following:

The extraordinary protections afforded by the First Amendment carry with them something in the nature of a fiduciary duty to exercise the protected rights responsibly a duty widely acknowledged but not always observed by editors and publishers. It is not asking too much to suggest that those who exercise First Amendment rights in newspapers or broadcasting enterprises direct some effort to protect the rights of an accused to a fair trial by unbiased jurors. ${ }^{263}$

The presumption of innocence is the foundation of the American criminal justice system and is of international importance in criminal matters. ${ }^{264}$ If pretrial publicity maintains its limitless ability to cover criminal matters at the expense of defendants, then the presumption of innocence will continue to diminish unless measures are taken to shield it. By making the presumption of innocence an explicit right, foreign legislatures have adopted legislation to protect the presumption of innocence from prejudicial media coverage. ${ }^{265}$

258. Contempt of Court Act 1981, c. 49 (Eng.), http://www.legislation.gov.uk/ukpga/ 1981/49\#commentary-c810785 [https://perma.cc/ANP2-AZCM]; DECLARATION OF THE RIGHTS OF MAn And of The Citizen, 1789, art. XI (Fr.).

259. Neb. Press Ass'n v. Stuart, 427 U.S. 539, 570 (1976).

260. See supra Part II.A.

261. Judy, supra note 8, at 542 (describing media power and governance of citizens).

262. Sheppard v. Maxwell, 384 U.S. 333, 362 (1966) (stating media coverage outweighed the administration of justice calling for stronger regulation measures to ensure balance).

263. 427 U.S. at 560.

264. Coffin v. United States, 156 U.S. 432, 453 (1895); Baradaran, supra note 2.

265. Declaration of the Rights of Man and of the Citizen, 1789, art. XI (Fr.). 
Because the presumption is not an explicit right in the United States and has been combined with the burden of proof by the Supreme Court, difficulty in safeguarding the presumption has dominated our criminal law. ${ }^{266}$ Therefore, the United States should separate the presumption of innocence from the burden of proof, affirming the distinction handed down in Coffin. ${ }^{267}$ Further, the presumption of innocence must be reinforced through legislation to restore balance between freedom of the press and the rights of defendants. This can be accomplished by two methods. First, Congress could instead enact legislation similar to England's Contempt of Court Act to restrict the press from prejudicial pretrial media coverage. ${ }^{268}$ Second, Congress can make the presumption of innocence an explicit right and allow courts to manage challenges based on First Amendment grounds. ${ }^{269}$ Regardless, action must be taken to reinforce the foundation of American criminal law and protect defendants' rights.

Permitting judges to use common sense and a realistic view of the impact of an unchecked media on judicial proceedings may indeed be a more effective alternative than merely relying on the current rigid First Amendment standards which romanticize a media which, arguably, no longer adequately fulfills its role as the promoter of an informed citizenry. ${ }^{270}$

The courts are in desperate need of adequate measures to maintain a balance between the presumption of innocence and the freedom of the press. ${ }^{271} \mathrm{Without}$ them, the presumption of innocence cannot hope to be shielded from pretrial publicity leading to a continued violation of a defendant's constitutional rights. ${ }^{272}$

266. Taylor v. Kentucky, 436 U.S. 478, 483-84 (1978).

267. 156 U.S. at 460.

268. Contempt of Court Act 1981, c. 49 (Eng.), http://www.legislation.gov.uk/ukpga/1981/ 49\#commentary-c810785 [https://perma.cc/ANP2-AZCM].

269. Declaration of the Rights of Man and of the Citizen, 1789, art. Xi (Fr.).

270. Judy, supra note 8, at 592.

271. Id. at 570-71 (describing failures of current methods of publicity control in the court).

272. Id. at 548-49 (outlining problematic exposure of bad journalism). 